\title{
RELEVANSI HUKUM POSITIF DAN HUKUM ISLAM
}

\author{
Oleh : \\ Abd. Halim Mushthofa *
}

\section{Abstrak,}

Sebagai seorang muslim dan sekaligus sebagai seorang warga Negara Republik Indonesia kadang mengalami kegamangan dan bahkan kebingungan dalam menghadapi dua ketentuan hukum yang sama-sama mengatur, disatu sisi peraturan perundang-undangan mengatur keharusan untuk melakukan suatu perbuatan sementara hukum Islam yang diyakininya mengatakan lain atau tidak perlu, lalu timbul pemikiran mana yang harus dipatuhi dan ditaati apakah hukum positif atau hukum Islam.

Masih adanya kasus nikah sirri, talak sirri, wakaf sirri dan kadang zakat dan wakaf sirri ini disebabkan antara lain karena adanya dua ketentuan yang berbeda dalam aturannya dan oleh karenanya menimbulkan konsekuensi hukum yang berbeda pula. Hukum positif bersumber pada hasil pemikiran manusia sedangkan hukum syar'i (hukum Islam) bersumber pada wahyu.

Sudah ada ikhtiar yang dilakukan untuk mencoba mengkompromikan kedua ketentuan hukum tersebut misalnya dengan cara kompilasi agar ketentuan hukum positif bisa berlaku efektif sekaligus sesuai dengan hukum Islam (syar'i). upaya merelevansikan ini muncul dari semangat dan keinginan umat Islam agar hukum positif yang berlaku juga dianggap hukum syar' $i$ (hukum Islam) sebagai produk dari sebuah Negara yang sudah dihukumi final sebagai Negara yang sah secara fiqih.

Kata Kunci : Relevansi, hukum positif, hukum Islam.

\section{Pendahuluan}

Idealnya sebuah peraturan perundang-undangan bisa berlaku efektif dan menumbuhkan banyak kemaslahatan

\footnotetext{
${ }^{*}$ IAI Tribakti Kediri.
} 
kehidupan masyarakat termasuk rasa aman/tentram dalam kehidupan rumah tangga. Efektifitas sebuah aturan bisa terjadi salah satunya adalah adanya topangan atau dukungan kuat dari masyarakat terhadap aturan itu.

Bagi umat muslim di Indonesia sebuah aturan pada umumnya akan didukung jika memang aturan tersebut bersumber dari aturan agamanya. Harapan dan dukungan itu selalu tercermin dalam setiap doa yang dipanjatkan dalam setiap khotbah jumat yang berbunyi:

$$
\text { اللهم إجعل بلد تتا إنذونسيا هذه بلدة طيبة تجرى فيها آحكامك وسنة رسولك }
$$

Artinya:"Ya Allah jadikan negeri kita Indonesia ini negeri yang thayyibah (baik) yang berlaku di dalamnya hukumhukumMu dan sunnah RasulMu..."

Berlakunya hukum yang bersumber dari Al Kitab dan $\mathrm{Al}$ Sunnah menjadi salah satu criteria negeri yang baik / baldatun thayyibah, jika tidak maka negeri tersebut dianggap bukan negeri yang baik yang dikhawatirkan akan mengalami banyak kendala dalam pelaksanaan berbagai macam ketentuan perundang-undangan.

Sementara negeri ini didirikan dengan semangat kesepakatan bahwa dasar Negaranya adalah pancasila yang berarti bukan berdasar agama walaupun pancasila tidak bertentangan dengan agama. Kondisi ini membawa konsekuensi tersendiri bagi terwujudnya ketentuan hukum Islam karena harus diseleksi terlebih dahulu keselarasannya dengan kondisi tersebut misalnya dengan keharusan mengakomodir kearifan lolal dan ke Indonesiaan, maka tidak mengherankan kadang muncul istilah fiqih Indonesia atau fiqih madzab Indonesia ${ }^{1}$. Hal ini tercermin dalam Undang-Undang Perkawinan, Undang-Undang Peradilan Agama dan Kompilasi Hukum Islam di Indonesia.

Berbagai ketentuan hukum keluarga Islam di Indonesia yang tertuang dalam hukum positif tersebut diatas, tidak jarang secara harfiyah kadang "bertentangan" dengan hukum / syari'at Islam. Kondisi seperti itu kadang memaksa warga muslim

\footnotetext{
${ }^{1}$ Marzuki Wahid, Fiqih Indonesia, ISIF, Cirebon, I, 2014, h.ix.
} 
Indonesia untuk secara "semebunyi-sembunyi" tetap menaati aturan syari'at agamanya sekalipun bertentangan dengan Perundang-undangan yang berlaku. Ini tercermin dari masih banyaknya masalah nikah sirri, talak sirri, bahkan zakat dan wakaf sirri, kondisi ini menunjukan adanya ketidak patuhan terhadap hukum positif yang berlaku dan akhirnya akan menimbulkan berbagai ekses dan akibat hukum yang tidak mudah.

Kondisi seperti ini tentu memerlukan solusi agar kenyamanan dan ketentraman batin umat Islam Indonesia benarbenar ada dan terjaga. Usaha-usaha untuk itu pernah dan telah diusahakan oleh berbagai kalangan termasuk di lingkungan organisasi keagamaan seperti Jam'iyah Nahdlatul Ulama' yang dalam sebuah keputusan Muktamarnya misalnya telah menetapkan bahwa Negara Indonesia yang didirikan pada Tahun 1945 dipandang sah secara fiqih ${ }^{2}$, sehingga konsekuensinya semua produk-produk hukum Negara juga akan dianggap sah sebagai hukum fiqih sekaligus hukum positif. Dengan pemikiran seperti ini diharapkan tumbuh kesadaran dan ketaatan tunggal bagi muslim Indonesia terhadap sebuah ketentuan Perundang-undangan yang berlaku. Langkah seperti itu juga merupakan ikhtiyar untuk merelevansikan hukum fiqih dengan hukum positif di Indonesia khususnya yang menyangkut hukum keluarga Islam.

\section{Pengertian Hukum Positif, Hukum Islam dan Keluarga Islam}

Hukum Positif adalah hukum yang berlaku di sebuah tempat saat ini seperti halnya di Negara Kesatuan Republik Indnesia. Hukum yang berlaku tersebut terdiri dari ketentuanketentuan atau aturan-aturan yang saling berhubungan dan saling menentukan, oleh karena itu aturan-aturan tadi merupakan suatu susunan dan tata hukum. Tata hukum itu sah dan berlaku bagi suatu masyarakat, jika dibuat dan ditetapkan oleh penguasa masyarakat itu, masyarakatnya itu sendiri disebut juga masyarakat hukum ${ }^{3}$.

\footnotetext{
${ }^{2}$ Sahal Mahfudz, Ahkam Al Fuqoha, LTNNU, 2004, h.593.

${ }^{3}$ Kansil, Pengantar Hukum Indonesia, Balai Pustaka, IX, 1993, h.3
} 
Hukum positif dikenal dalam istilah arab dengan Qanun Wadh' ${ }^{4}$ yang dalam kamus Inggris dikenal dengan Positive Law, senada dengan itu dalam istilah ilmu ushul figh dikenal dengan hukum wadh'i yaitu hukum yang diproses dan dibuat melalui perumusan dan penyusunan para ahli dan para pakar hukum Islam, di samping itu ada istilah Hukum Syar'i yang proses pengambilannya dari syara' dan atau nash-nash wahyu serta ijtihad para ahli (mujtahid) ${ }^{5}$.

Ketentuan peraturan perundang-undangan yang berlaku saat ini yang mengatur berbagai ketentuan hukum termasuk hukum keluarga muslim antara lain Undang-Undang No.1 Tahun 1974 Tentang Perkawinan, Undang-Undang No.7 Tahun 1989 Tentang Peradilan Agama (yang mengalami beberapa kali perubahan dan penyempurnaan), dan Instruksi Presiden No.1 Tahun 1991 Tentang Kompilasi Hukum Islam dan bahkan ada rancangan atau konsep pembaharuan hukum keluarga Islam yang pernah digarap oleh Team Departemen Agama RI yang kemudian dibekukan karena kurang mendapat dukungan di parlemen. $^{6}$

Adapun hukum Islam sekalipun tidak banyak digunakan pada literatur Arab, yang dimaksudkan adalah hukum yang bersumber dari dan menjadi bagian agama Islam $^{7}$, sekalipun demikian hukum Islam memiliki dan terdiri dari beberapa istilah antara lain hukum Islam itu sendiri, syari'at Islam dan fiqih Islam.

Hukum Islam diartikan sebagai seperangkat peraturan berdasarkan wahyu Allah dan Sunnah Rasul tentang tingkah laku manusia mukallaf yang diakui dan diyakini mengikat untuk semua yang beragama Islam, sedangkan fiqih didefinisikan sebagai ilmu tentang hukum-hukum syar'i yang bersifat amaliyah yang digali dan ditemukan melalui penalaran dan istidlal seorang mujtahid dari dalil-dalil yang sudah terperinci

${ }^{4}$ Ahmad Warson Munawwir, Kamus Al Munawwir, Pustaka Progresif, Surabaya, XIV, 1997, h.1565

${ }_{5}$ Muhammad Abdu Al 'Athi, Al Hukmu Al Syar'i, Dar Al Hadits,

Kairo, 2008, h.16

${ }^{6}$ Marzuki Wahid, h.274

${ }^{7}$ Muhammad Daud Ali, Hukum Islam, Raja Grafindo Persada, Jakarta, XX, 2014, h.42 
dalam nash Al Qur'an dan Al Sunnah, adapun istilah syari'at digunakan untuk segala titah Allah yang berhubungan dengan tingkah laku manusia selain urusan akhlaq, yang urusan akhlaq itu telah diatur tersendiri dalam ilmu tasawwuf dan wijdaniyah (ilmu rasa dan bersifat batiniyah), dan kadang istilah syari'ah itu dikhususkan bagi ketentuan yang bersumber langsung dari nash Al Qur'an dan Al Hadits yang bersifat qoth' $i$ (yang ketentuan hukumnya bersifat pasti). Dari penggunaan ketiga istilah tersebut ada yang menganggapnya sama dan ada yang mencoba membedakan dalam beberapa hal. ${ }^{8}$

Adapun yang dimaksud dengan istilah keluarga muslim ialah keluarga yang anggota-anggotanya terdiri atas orang-orang yang beragama Islam. Termasuk dalam kategori ini adalah keluarga yang kepala keluarganya beragama Islam, walaupun mungkin didalam keluarga tersebut ada anggota keluarga tertentu yang memeluk agama lain. Perlu pula dipertimbangkan pemberlakuan hukum keluarga Islam di tengah masyarakat untuk menentukan layak-tidaknya sebuah keluarga dikategorikan sebagai keluarga muslim. Keislaman kepala keluarga dalam menentukan keluarga muslim memiliki makna tersendiri mengingat peranannya yang sangat penting dan pengaruhnya yang sangat kuat dalam sebuah keluarga, sedang pertimbangan pengamalan hukum Islam dimaksudkan untuk mengantisipasi kemungkinan salah kaprah bagi kehidupan keluarga muslim yang semata-mata bersifat formalistik. ${ }^{9}$

\section{Perkembangan Hukum Keluarga Islam di Indonesia dan Dunia Islam}

Untuk mewujudkan satu hukum Nasional bagi bangsa Indonesia yang terdiri dari berbagai suku bangsa dan agama yang berbeda terlebih ada warisan keragaman sistem hukum di masa lalu, memang tidaklah mudah apalagi jika dikaitkan dengan agama Islam yang juga mengatur berbagai hubungan manusia yang satu dengan yang lainnya termasuk hukum keluarga. Oleh karena itu, dalam membangun hukum Nasional

\footnotetext{
${ }^{8}$ Amir Syarifuddin, Ushul Fiqh, Logos, Jakarta, I, 1997, h.4

${ }^{9}$ Muhammad Amin Suma, Hukum Keluaraga Islam di Dunia Islam, Raja Grafindo Persada, 2004, h.21
} 
di Negara yang mayoritas beragama Islam, perlu dan harus memperhatikan benar-benar unsur hukum agama.

Khusus dalam perkembangan hukum keluarga Islam di Indonesia mengalami fase-fase panjang sejak masa kerajaan Islam, masa penjajah dan masa kemerdekaan sampai sekarang. Fase pelaksanaannya juga terpengaruh dengan berbagai teori yang berkembang dari masa ke masa.

Pada masa kerajaan Islam, hukum keluarga bagi muslim adalah hukum Islam yang banyak tertulis dalam kitab-kitab fiqih, bahkan kondisi itu tetap berlaku sampai masa awal penjajahan belanda di Indonesia, sehingga muncul sebuah teori receptio in complexu yang dikembangkan oleh LWC van den Berg (1845-1927) yang pada pokoknya, teori itu menyatakan bahwa hukum mengikuti agama yang dianut seseorang, maka jika seorang muslim yang berlaku baginya adalah hukum Islam, oleh karenanya di masa-masa itu hukum keluarga Islam mengikuti teks-teks yang banyak tertulis dalam kitab-kitab fiqih bahkan yang bermadzab Syafi'i.

Fase berikutnya masa akhir penjajah muncul teori yang berbeda bahkan berlawanan yaitu teori resepsi (receptie theorie) yang dikembangkan oleh Christian Snouck Hurgronje (18571936) yang inti teori itu adalah bahwa yang berlaku bagi orang Islam adalah hukum adat, oleh karenanya bila belum menjadi hukum adat belum dianggap hukum sekalipun sudah menjadi hukum Islam ${ }^{10}$. Walaupun teori ini mendapat banyak tantangan dari para pakar hukum muslim, namun teori itu tetap digunakan untuk mengatur berbagai ketentuan hukum umat Islam di Indonesia bahkan pengaruh teori tersebut masih terasa sampai masa setelah kemerdekaan, terbukti dari munculnya beberapa aturan perundang-undangan yang mengatur umat Islam tetapi kadang ditemui secara harfiah bertentangan dengan teks yang ada dalam ketentuan fiqih Islam.

Di dunia Islam atau di Negara-Negara yang berpenduduk muslim, ketentuan perundang-undangan yang mengatur hukum keluarga Islam juga mengalami hal serupa kecuali beberapa Negara yang tidak pernah terjajah. Umat muslim dunia yang pada tahun 1999 telah mencapai 1,4 milyar tersebar di berbagai

${ }^{10}$ Muhammad Daud Ali. Al Hukmu, h.242-243. 
Negara dan mayoritas bermukim di Negara-Negara muslim (dunia Islam) yang luasnya kurang lebih 39 juta $\mathrm{Km}^{2}$ atau $25 \%$ luas dunia ${ }^{11}$

Negara-Negara yang didiami oleh umat muslim dalam memberlakukan hukum keluarga Islam ada tiga kelompok yaitu:

1. Negara-Negara yang memberlakukan secara klasik dan tradisional menurut madzhab-madzhab yang ada dan tidak pernah berubah serta tidak terkodifikasi seperti Saudi Arabia, Yaman, Bahrain dan Kuwait.

2. Negara-Negara sekuler tidak lagi menggunakan hukum keluarga Islam, tetapi sudah memberlakukan hukum dan perundang-undangan modern seperti Turki, Albania dan sebagainya.

3. Negara-Negara yang telah melakukan pembaharuan hukum keluarga Islam dan memberlakukan hasil pembaharuan hukum tersebut seperti Mesir, Yordania, Siria, Tunisia, Indonesia dan lain-lain. ${ }^{12}$ Hukum keluarga Islam tersebut telah dituangkan dalam bentuk perundangundangan tertulis di masing-masing Negara yang bersangkutan.

\section{Hukum Positif Produk Negara dalam Perspektif Fiqih}

Hukum keluarga Islam dan sebagian hukum Islam lainnya sebagaimana perkembangannya dari masa ke masa melalui fasefase dengan pembaharuan dan penyempurnaan, akhirnya telah menjadi hukum positif sebagaimana tertuang dalam beberapa undang-undang Negara seperti yang telah dijelaskan dalam pembahasan sebelumnya dan menjadi salah satu pertimbangan keputusan penyelesaian sengketa hukum keluarga di berbagai tingkatan peradilan. Sementara bagi sebagian umat Islam hukum keluarganya mengikuti ketentuan hukum syar'i yang tertulis dalam berbagai kitab fiqih.

Permasalahan kemudian muncul bagaimana kedudukan, kaitan dan relevansi hukum positif tersebut dengan ketentuan hukum fiqih, dan bagaimana pula jika dalam beberapa pasal undang-undang tersebut terdapat ketentuan yang berbeda dan

\footnotetext{
${ }^{11}$ Suma, Hukum, h.140

${ }^{12}$ Ibid. 148
} 
bahkan bertolak belakang dengan hukum syar'i yang ada dalam kitab-kitab fiqih itu, dan bagi seorang muslim yang sekaligus warga Negara mana yang harus dipatuhi di antara keduanya, misalnya ketentuan yang menyatakan bahwa nikah dianggap sah bila dicatatkan, talak hanya dinyatakan jatuh bila diikrarkan di depan sidang pengadilan dan ketentuan-ketentuan sejenisnya.

Dalam menghadapi kondisi seperti itu para pakar dan ulama memerinci dengan beberapa kemungkinan antara lain sebagai berikut: Pertama, hukum positif yang menetapkan ketentuan yang tidak didasarkan pada petunjuk nash yang shorih (jelas) dari Al Qur'an maupun Al Sunnah, maka ketentuan tersebut dapat diterima sebagai sebuah peraturan dan kemudian dapat diikuti dan ditaati. Sesuatu yang tidak disinggung atau tidak ditetapkan secara tegas oleh nash Qur'an dan Hadits memang dapat memberi ruang bagi para pakar dan ahli untuk dikreasikan dan dikembangkan menjadi berbagai aturan bagi umat, melalui ijtihad para mujtahid yang kemudian menghasilkan berbagai fatwa hukum yang mengatur hal-hal yang menyangkut kehidupan masyarakat luas. Bisa diterimanya hukum positif seperti di atas didasarkan pada pendapat para ulama misalnya pendapat Syeikh Abd Al Muhsin Al I'bad yang mengutip penjelasan Amiril Mukminin Utsman bin Affan r.a. tentang pentingnya kedudukan/posisi penguasa yang keberadaannya dapat melahirkan dan mewujudkan kebaikan dan kemaslahatan umat. Dalam pendapatnya Khalifah Utsman mengatakan bahwa sesungguhnya Allah niscaya juga akan mengatur umat melalui Sulthon/Penguasa terhadap hal-hal yang tidak ada dalam Al Qur'an, sebab kadang sungguh ada sebagian orang yang gemar membaca Al Qur'an tapi ia diam saja dan tidak pernah tersentuh hatinya untuk melakukan sesuatu bila ia menyaksikan kerusakan dan pelanggaran hukum, bahkan ia justru lebih takut pada kebijakan penguasa. ${ }^{13}$

Imam Al Suyuthi berpendapat dalam mengomentari sebuah kaidah yang pernah dirumuskan oleh Imam Syafi'i yang maksudnya bahwa "kedudukan seorang penguasa atas rakyatnya, seperti kedudukan wali yatim (orang yang diberi mandat hukum untuk mengurus harta benda anak yatim), Imam

\footnotetext{
${ }^{13}$ Abd Al Muhsin Al I'bad, Syarah Sunan Abi Dawud, tt, I h.2
} 
Al Suyuthi kemudian mengutip pendapat Khalifah Umar Bin Khattab r.a. (melalui sanad yang panjang) yang pernah mengatakan bahwa beliau memposisikan diri dalam penguasaan harta Allah, seperti posisi wali yatim, jika beliau memerlukannya beliau pakai jika beliau sudah punya beliau kembalikan, lalu jika beliau tidak memerlukannya lagi beliau akan sungguh-sungguh menjaga diri dan tidak menyentuhnya. Dari pemahaman seperti ini Imam Al Suyuthi kemudian merumuskan kaidah:

\section{تصرّف الإمام على الرعية منوط بالمصلحة. \\ Artinya: "kebijakan Imam/Penguasa atas rakyatnya harus selalu mempertimbangkan kemaslahatan. ${ }^{14}$}

Kedua, hukum positif yang menetapkan ketentuan perundang-undangan yang secara jelas-jelas bertentangan dengan hukum syar'i, maka aturan tersebut tidak bisa diterima dan harus ditolak. Para ulama tegas dalam menyikapi hal seperti ini sebagaimana pendapat Imam Asyqollani dalam uraian beliau tentang hadits Nabi yang berbunyi:

$$
\text { بمعية فلا يسمع و لاطاعة المر المسلم فيما أحبّ أوكره مالم يؤمر بمعصية فاذا أمر }
$$

Artinya : wajib mendengar dan patuh bagi seorang muslim atas segala perintah dan aturan penguasa suka atau tidak suka (kepatuhan itu) selama tidak memerintahkan kemaksiyatan, jika perintah dan aturan itu berisi kejahatan dan maksiyat maka sama sekali tidak boleh dipatuhi. Imam Al Asyqollani mengatakan tidak wajib menaatinya, bahkan haram mematuhinya terutama bagi yang bisa dan mampu mencegahnya.

Ketiga, hukum positif yang menetapkan ketentuan yang juga telah ditetapkan oleh hukum syar'i/fiqih sebagai wajib atau sunnah, maka menurut fiqih ketentuan tersebut harus dipatuhi,

${ }^{14}$ Jalaluddin Al Suyuthi, Al Asybah wa Al Nadho'ir, Dar Al Kutub Al Ilmiah, Beirut, I, 1403 H, h.121

${ }^{15}$ Ahmad Ibnu Al Hajar Al Asyqollani, Fath Al Baari Syarah Shohih Al Bukhori, Dar Al Kutub Al Ilmiyah, Beirut, I,1989, Juz 12, h.154 
sedang apabila hukum positif menetapkan ketentuan yang telah ditetapkan fiqih sebagai hukum mubah yang banyak mengandung manfaat bagi kepentingan umum, maka ketentuan tersebut juga wajib dipatuhi. Pendapat seperti ini misalnya dikemukakan oleh Imam Muhammad Nawawi Al Jawi, menurut beliau bahwa jika diperintahkan oleh penguasa sesuatu aturan yang juga telah diwajibkan oleh hukum syara', maka akan lebih kuat kewajiban mematuhinya sedang jika yang diatur oleh penguasa tersebut merupakan hal yang sunnah atau hal yang disunnahkan maka ketentuan tersebut menjadi wajib dipatuhi, demikian juga jika penguasa membuat aturan yang oleh fiqih dihukumi mubah tapi mengandung banyak kemaslahatan bagi masyarakat umum, maka ketentuan tersebut wajib dipatuhi. ${ }^{16}$

Demikian pula Imam Muhammad Arofah Dasuqi mengatakan bahwa apabila Imam/Penguasa memerintahkan sesuatu aturan yang hukumnya mubah atau sunnah, maka menjadi wajib hukumnya untuk mematuhi jika aturan tersebut memang benar-benar mengandung banyak kemaslahatan umum.

Pandangan yang lain muncul dari pakar fiqih Indonesia yang hidup di masa reformasi seperti KH. Muhammad Ahmad Sahal Mahfud, beliau mengatakan bahwa "fiqih tetap sebagai etika sosial bukan sebagai hukum Negara". ${ }^{18}$ Hal ini tentu bisa dipahami jika ketentuan yang ada dalam hukum fiqih tersebut, belum dan atau tidak diformalkan sebagai bagian hukum positif oleh penguasa. Pernyataan ini senada dengan pernyataan Imam Malik Bin Annas (w. Tahun 800M/179 H) guru Imam Syafi'i, yang pernah menolak hasil karya-karya fiqihnya untuk dijadikan undang-undang Negara oleh penguasa Abbasiyah waktu itu. ${ }^{19}$ Berbeda dengan usulan Ibnu Al Muqoffa (w. 139 H/756 M) pada khalifah Abbasiyah agar diadakan unifikasi (kesatuan hukum) dari sekian perbedaan pendapat yang ada, dan hasil

\footnotetext{
${ }^{16}$ Muhammad Nawawi Al Jawi, Nihaya Al Zain, Dar Al Fiqr, Beirut, tt, Juz 1 , h. 122

${ }^{17}$ Muhammad Arofah Dasuqi, Hasyah Dasuqi Ala Syarh Al Kabir, Dar Al Fiqr, Beirut, tt, I, h.407

${ }^{18}$ Husain Muhammad, Fiqih Sosial Kyai Sahal, Risalah NU, edisi 44, Tahun VII, 1435 H/2014 M, h.40

${ }^{19}$ Ibid.
} 
unifikasi ini menjadi hukum yang diberlakukan Negara sebagaimana usaha yang pernah juga dilakukan sebelumnya oleh khalifah Umar Ibnu Abd Al Azis dari Dinasti Bani Umayyah. $^{20}$

\section{Relasi Agama dan Negara dalam Perspektif Fiqih}

Hukum positif yang mengatur berbagai ketentuan hukum termasuk hukum keluarga- diproses dan kemudian disahkan oleh Negara sebagai sebuah produk hukum yang kemudian disebut hukum positif. Dalam memproses sebuah produk hukum Negara telah mengakomodir berbagai praktek/pelaksanaan hukum yang dianut oleh bangsa indonesia termasuk hukum yang berlaku bagi umat Islam, sekalipun produk-produk hukum Negara tersebut selalu dipengaruhi oleh politik hukum penguasa pada saat itu. ${ }^{21}$

Keberadaan Negara itu sendiri dalam pandangan fiqih Islam terdapat beberapa teori. Beberapa peneliti menyimpulkan bahwa dalam kaitan agama Islam dan Negara ada tiga kelompok utama pemikir politik Islam kontemporer. Pandangan ketiga kelompok tersebut dipengaruhi oleh beragam faktor yang antara lain kemunduran dunia Islam itu sendiri, dominasi dan penjajahan Negara eropa karena keunggulannya di bidang ilmu, teknologi dan organisasi. ${ }^{22}$

Peneliti dan penulis lain lebih menegaskan temuan-temuan di atas dengan memunculkan tiga paradigma yaitu integralistik, sekularistik dan simbiotik. ${ }^{23}$ Sementara peneliti lainnya lagi memilih dengan dua kelompok/golongan yaitu golongan yang tidak mewajibkan adanya Imam dengan berbagai alasan dan golongan yang menganggap agama Islam terpisah dari Negara dengan berbagai alasan pula. ${ }^{24}$ Lebih lanjut, para peneliti

${ }^{20}$ Abdul Halim Barkatullah, Hukum Islam, Pustaka Pelajar, Yogyakarta, I, 2006, h.132-133

${ }^{21}$ Marzuki, Fiqih, h. 24

${ }^{22}$ Munawir Sjadzali, Islam dan Tata Negara, UI Press, Jakarta, cet.III, 1991, h.204-205 2005, h.57

${ }^{23}$ Jaih Mubarok, Fiqih Siyasah, Pustaka Bani Quraisy, Bandung, 1,

${ }^{24}$ Djazuli, Fiqih Siyasah, Kencana, Jakarta, cet.IV, 2009, h.87-89 
menjelaskan lebih detail tentang perbedaan garis besar paradigma tersebut sebagai berikut, Pertama, Paradigma integralistik, dalam paradigma ini agama dan Negara menyatu (integrated). Wilayah agama meliputi Negara oleh karenanya kepala Negara adalah pemegang kekuasaan agama dan Negara sekaligus seperti yang dianut kebanyakan kaum Syi'ah.

Kedua, Paradigma sekularistik, paradigma ini menegaskan pemisahan antara agama dan Negara, oleh karenanya paradigma ini menolak pendasaran Negara pada Islam, selanjutnya tidak ada ketentuan-ketentuan keagamaan yang diatur melalui legislasi Negara.

Ketiga, Paradigma simbiotik, dengan meminjam istilah ilmu biologi simbiosis mutualisma, menurut paradigma ini agama dan Negara berhubungan secara simbiotik hubungan yang bersifat timbal balik saling memerlukan, dalam hal ini agama memerlukan Negara untuk bisa berkembang dan sebaliknya Negara perlu agama untuk mendapatkan bimbingan etika dan moral spiritual. $^{25}$ Paradigma yang ketiga ini merupakan jalan tengan di antara integralistik dan sekuleristik dan sesuai dengan kondisi riil kehidupan bangsa Indonesia, sekalipun kadang dalam perjalanannya memunculkan rivalitas dominasi di antara agama dan Negara tersebut seperti yang terjadi selama ini dari era ke era sampai era reformasi.

Dengan gambaran seperti itu bisa saja proses politik hukum Islam di Indonesia mempunyai kecendrungan meningkatnya aspek agama ke Negara misalnya dengan disahkannya beberapa ketentuan hukum Islam melalui proses legislasi,walaupun tidak seluruhnya perlu dilakukan.

Ketentuan-ketentuan hukum Islam yang perlu dijadikan hukum Nasional adalah hukum yang pelaksanaannya memang memerlukan bantuan kekuasaan Negara dan berkaitan langsung dengan ketertiban umum seperti yang menyangkut hukum keluarga Islam. ${ }^{26}$

\section{Kesimpulan}

${ }^{25}$ Marzuki, Fiqih, h.31

${ }^{26}$ Sirajuddin M, Legislasi Hukum Islam di Indonesia, Pustaka Pelajar, cet.I, 2008, h.147 
Suatu kenyataan bahwa masih adanya ketaatan ganda bagi seorang muslim warga Negara Indonesia terhadap beberapa ketentuan perundang-undangan yang diyakininya belum sesuai dengan hukum yang diyakininya pula sebagai hukum agama. Di saat harus memilih dan menentukan kepatuhan, mereka lebih memilih patuh pada hukum agamanya walaupun dengan sembunyi-sembunyi, padahal akibat hukum dari sikap seperti itu sangat kompleks dan tidak mudah menyeleseikannya seperti kasus anak perempuan hasil perkawinan sirri yang akan menikah secara resmi, wali nikahnya diambil alih oleh Kepala Kantor Urusan Agama sebagai wali hakim karena wali nasabnya dianggap tidak ada atau tidak sesuai dengan dokumen resmi yang dipersyaratkan.

Kondisi kepatuhan warga muslim Indonesia seperti itu memerlukan langkah-langkah penyeleseian hukum yang bisa dipahami dan diterima semua pihak. Warga muslim perlu mempelajari dan kemudian menyadari bahwa ketentuan hukum fiqih apabila kemudian ditetapkan menjadi hukum positif, berarti akan mengikat semua warga Negara dan wajib mematuhinya, mengingat bahwa Negara yang memproses ketentuan hukum tersebut sudah dianggap sah dalam pandangan fiqih, sesuai dengan kaidah yang berbunyi:

$$
\text { الرض بالثئ رضا بماينو لا منه. }
$$

Artinya: "menerima dan menyetujui sesuatu (keputusan) maka harus menerima dan menyetujui produk (hukum) yang dilahirkannya. ${ }^{27}$

Ketentuan perundang-undangan yang sudah puluhan tahun itu, belum tentu juga semua warga Negara muslim mengetahuinya atau menyadarinya, sementara penyelenggara Negara atau petugas Negara kadang berfikir "hitam-putih" yang kadang bisa menimbulkan masalah, oleh karena itu hal ini menyangkut problem sosialisasi yang belum optimal.

${ }^{27}$ Ade Dedi Rohayana, Ilmu Qowaid Fiqihiyah, Gaya Media Pratama, Jakarta, I, 2008, h.166 lihat pula Mukhtar Yahya, Dasar-dasar Pembinaan Hukum Islam, Ma'arif, Bandung, I, 1986, h.546. 
Langkah-langkah yang terus perlu dilakukan adalah penyelenggaraan "dialog-dialog hukum" terus menerus yang melibatkan para pakar dan penyelenggara Negara sebagai bagian proses legislasi sebuah ketentuan hukum. Dengan demikian menjadi wajar apabila terjadi amandemen dan perubahan sebuah peraturan perundang-undangan untuk menuju kesempurnaan, dan dalam rangka mewujudkan sosok seorang "muslim Indonesia lahir batin". 


\section{DAFTAR PUSTAKA}

A Djazuli, Fiqih Siyasah, Jakarta, Kencana, Cet. Ke IV, 2009.

Al Athi, Muhammad Abd, Al Hukmu Al Syar'i, Kairo, Dar Al Hadits, 2008.

Al 'Ibad, Abd Al Muhsin, Syarah Sunan Abi Dawud, tt.

Al Suyuthi, Jalaluddin, Al Asybah wa Al Nadh'oir, Beirut, Dar Al Kutub Al Ilmiah, I, $1403 \mathrm{H}$.

Al Asyqollani, Ahmad Ibnu Al Hajar, Fath Al Baari Syarah Shohih Al Bukhori, Beirut, Dar Al Kutub Al Ilmiah, I, 1989.

Al Jawi, Muhammad Nawawi Bin Umar, Nihayatu Al Zaini, Beirut, tt.

Ali, Muhammad Daud, Hukum Islam, Jakarta, Rajawali Pers, Cet. Ke XX, 2014.

Barkatullah, Abdul Halim, Hukum Islam, Jogjakarta, Pustaka Pelajar, Cet. Ke I, 2006.

Dasuki, Muhammad Arofah, Hasyiyah Dasuki Ala Syarh Al Kabir, Beirut, Dar Al Fikr, tt.

Kansil, Pengantar Hukum Indonesia, Jakarta, Balai Pustaka, Cet. Ke IX 1993.

Koto, Alaiddin, Filsafat Hukum Islam, Jakarta, Raja Grafindo Persada, Cet. Ke II, 2013

Muhammad, KH. Husein, Fiqih Sosial Kyai Sahal, Risalah PBNU, eds. 44 Tahun VII, 2014.

Mubarok, Jaih, Fiqih Siyasah, Bandung, Pustaka Bani Quraisy, 2005. 
Mahfudh, KH. MA. Sahal, Ahkam Al Fukoha, Surabaya, LTN NU Jawa Timur, Cet. Ke I, 2004.

Nata, Abuddin, Masail Al Fiqhiyyah, Jakarta, Kencana, Cet. Ke II 2006.

Rohayana, Ade Dedi, Ilmu Qawa'id Fiqhiyyah, Jakarta, Gaya Media Pratama, 2008.

Sjadzali, Munawir, Islam dan Tata Negara, Jakarta, UI Press,Cet. Ke III 1991.

Sirajuddin, Legislasi Hukum Islam, Jogjakarta, Pustaka Pelajar, Cet. Ke I, 2008.

Suma, Muhammad Amin, Hukum Keluarga Islam di Dunia Islam, Jakarta, Raja Grafindo Persada, 2004.

Syarifuddin, Amir, Ushul Fiqh, Jakarta, Logos Wacana Ilmu 1977.

Tamrin, Dahlan, Kaidah-Kaidah Hukum Islam, Malang, UIN Maliki Press, 2010.

Wahid, Marzuki, Fiqh Indonesia, Cirebon, Institut Studi Islam Fahmina, 2014.

Yahya, Mukhtar, Dasar-Dasar Pembinaan Hukum Fiqh-Islami, Bandung, Al Ma'arif, Cet. Ke X, 1986. 